\title{
Društvene i političke okolnosti u doba izlaženja časopisa Život (1919.-1944.) i Obnovljeni Život (1971.-2019.)
}

\author{
Agneza Szabo*
}

\begin{abstract}
Summary
U prilogu se donosi pregled najvažnijih društvenih i političkih okolnosti kroz koje je prolazio hrvatski narod tijekom 20. stoljeća, a zajedno s njim $i$ časopis Život, odnosno Obnovljeni Život. O značenju i sadržajima toga časopisa ovdje se ne govori, ali je on i njegova stota obljetnica sastavni dio hrvatske povijesti. Zato su istaknuti u naslovu i njima u čast posvećen je ovaj rad. U ovom radu riječ je o odabiru niza društvenih i političkih okolnosti koje su uzrokovane teškim političkim nepravdama od strane vladajućih režima i struktura moći u kojima se hrvatski narod našao, i to ne svojom voljom. Njihova je bit teško ograničavanje ljudskih prava i sloboda. I u takvim okolnostima hrvatski je narod u osloncu na svoje trajne povijesne i kulturne vrijednosti, među kojima su i katolička vjera $i$ Sveta Stolica, tražio izlaz, koji je, zahvaljujući i promjenama u svijetu, u čijem je žarištu i Drugi vatikanski sabor, i pronalazio. Od tada, i nakon pada Berlinskoga zida, promjene su bile neizbježne. Nažalost, zbog velikosrpske agresije primoran je zakonito se braniti i uz Božju pomoć izvojevati zasluženu pobjedu u Domovinskom ratu (1991.-1995.), te međunarodno priznanje svoje suverenosti $i$ vlastite države - Republike Hrvatske (1992.). Potom i ulazak u NATO i Europsku uniju, u kojoj danas uživa zasluženi ugled. Veliku potporu u tome pružala mu je Sveta Stolica, i osobno sveti otac Ivan Pavao II.
\end{abstract}

Ključne riječi: Hrvatska; demokracija; režimi; velikosrpska agresija; Domovinski rat; Sveta Stolica

\section{Uvod}

O društvenim i političkim okolnostima kroz koje je prolazio hrvatski narod tijekom proteklih sto godina napisano je mnogo tekstova i s različitih stajališta. U žarištu tih zbivanja, kako se ovdje i navodi, bila su teška kršenja ljudskih prava i sloboda, osobito vjerskih i nacionalnih sloboda. Tu su i nametnuti ratovi i mno-

* Dr. sc. i dr. h. c. Agneza Szabo, u mirovini. E-adresa: agneza.szabo@zg.t-com.hr 
gobrojne ljudske žrtve i progoni, osobito nakon 1945. godine i u desetljećima koja su slijedila. Nakon započetih promjena u svijetu, među kojima je Drugi vatikanski sabor i pad Berlinskoga zida, i kod nas su bile očekivane promjene, i to u smislu ostvarenja ljudskih prava i sloboda. Nažalost, zbog velikosrpske agresije hrvatski je narod primoran na zakonitu obranu - Domovinski rat. U takvim uvjetima i uz velike žrtve konstituirana je slobodna i demokratska hrvatska država - Republika Hrvatska.

Ovaj rad posvećen je 100. obljetnici izlaženja časopisa Život (1919.-1944.), odnosno Obnovljeni Život (1971.-2019.), ali ne i njihovim sadržajima, koji zahtijevaju zaseban prikaz. Na temelju odabrane relevantne literature prikazan je u dvije cjeline. Za razdoblje između 1919. i 1944., kada je časopis Život prestao izlaziti, donosi se nešto opširniji pregled najvažnijih društvenih i političkih okolnosti, jer o njima postoji potreban povijesni odmak. Događaji nakon 1971., kada je časopis ponovno počeo izlaziti pod naslovom Obnovljeni Život, naša su suvremenost, te se zato oni ovdje, unatoč dužemu vremenskomu razdoblju, navode u znatno kraćem odabiru povijesnih činjenica u odnosu na prethodno razdoblje. Drugim riječima, u radu se donosi sažeti pregled bitnih i odabranih društvenih i političkih okolnosti u kojima se je nalazila Hrvatska u vrijeme izlaženja časopisa Život, odnosno Obnovljeni Život.

\section{Hrvatska nakon ulaska u Kraljevstvo Srba, Hrvata i Slovenaca}

Nova država Kraljevstvo Srba, Hrvata i Slovenaca (SHS), u koju hrvatski narod nije ušao svojom voljom (1. prosinca 1918.), jer nisu održani izbori, nastala je na temelju dviju političkih koncepcija: na politici Svetozara Pribičevića, koje je bit stvaranje nacionalnoga jugoslavenskoga unitarizma, koji je u državnom centralizmu vidio sredstvo za stvaranje jugoslavenske nacije. Za predsjednika vlade Nikolu Pašića nova država - Kraljevstvo SHS — bila je uspostavljena kao proširena Srbija, s vladajućom srbijanskom dinastijom, političkim strankama, vojskom, policijom, zakonodavnim i poreznim sustavom.

Već na samom početku uspostave Kraljevstva SHS brzo se je pokazalo da ono nije u stanju braniti teritorijalnu cjelovitost zemlje niti donijeti ustav koji će svim narodima koji su ušli u njezin sastav jamčiti ljudska prava i slobode.

Što se tiče teritorijalne cjelovitosti, predstavnici Kraljevstva SHS nisu uspijevali na Mirovnoj konferenciji u Parizu (1919./20.) oduprijeti se pritisku Italije, koja je tražila svoja tobožnja prava na Istru, i dio Dalmacije s pripadajućim otocima, koje su joj Saveznici i obećali tajnim Londonskim ugovorom 1915. godine, uz uvjet da napusti ratni blok Centralnih sila i pristupi silama Antante (Macan, 1992, 391-392).

Konačno je na Konferenciji, uz pritisak Saveznika i sve veću popustljivost jugoslavenskih pregovarača, zaključen nepovoljan ugovor s Italijom u Rapallu 1920. godine, poznat pod nazivom Rapalski ugovor. Njime su Italiji pripali Istra, grad Zadar s okolicom, otoci Cres, Lošinj, Lastovo i Palagruža, a Rijeku su Talijani već prije zaposjeli. Zbog takve situacije iz Istre se je iselilo u druge dijelove 
Hrvatske do izbijanja Drugoga svjetskoga rata (1939.) više od 100.000 Hrvata, osobito u grad Zagreb, više od 30.000 u inozemstvo, te u SAD. I poslije su jugoslavenske vlade često popuštale Italiji, što je izazivalo velika nezadovoljstva u Hrvatskoj. Godine 1924. potpisale su Kraljevina SHS i Kraljevina Italija u Rimu ugovor kojim je već ranije zaposjednuti grad Rijeka prepušten Italiji (Macan, 1992, 392; Pavličević, 2000, 340-342; Szabo-Labus, 2012, 250-251).

\section{Od Vidovdanskoga ustava do diktature (1921.-1929.)}

\subsection{Ustavno uređenje nove države Kraljevine Srba, Hrvata i Slovenaca}

Ustav nove države imala je donijeti ustavotvorna skupština izabrana 1920., za koju su izbori provedeni prema nedemokratskom izbornom redu, koji je odgovarao režimskim strankama i pod redarstvenim terorom, i stoga su one dobile većinu glasova. Zbog toga Radićeva Hrvatska pučka seljačka stranka (HPSS), unatoč visokoj potpori birača u Hrvatskoj, mijenja naziv u Hrvatska republikanska seljačka stranka (HRSS), i nije htjela ući u ustavotvornu skupštinu, kao ni zastupnici Hrvatske stranke prava. Iz skupštine su pred izglasavanje ustava izišli i zastupnici ostalih hrvatskih političkih stranaka (Hrvatske zajednice i Hrvatske pučke stranke). Na izglasavanju ustava nisu bili prisutni ni zastupnici Komunističke partije Jugoslavije (KPJ), jer je njihova djelatnost zabranjena Obznanom iz prosinca 1920. godine.

Ustavotvorna skupština proglasila je novi ustav 28. lipnja 1921., na Vidovdan po pravoslavnom kalendaru, pa otuda i naziv Vidovdanski ustav. Budući da je donesen običnom, a ne dvotrećinskom većinom, i bez prisutnosti hrvatskih zastupnika, Radić i njegova stranka nisu htjeli priznati novi ustav.

Ustavom je proglašena Kraljevina Srba, Hrvata i Slovenaca kao ustavna, parlamentarna i nasljedna monarhija s iznimnim ovlastima kralja, među kojima je i pravo kralja na raspuštanje narodne skupštine. Zadržan je državni unitarizam, centralizam i kapitalistički sustav, time i privatno vlasništvo, ali i narodna i društvena neravnopravnost i velikosrpska prevlast. Ustav je među Hrvatima izazvao veliko ogorčenje zbog njegova sadržaja. Njime je Hrvatska izgubila bitne elemente svoje višestoljetne državnosti: sabor kao parlament, domobranstvo kao vojsku te vladu i bana kao prvoga čovjeka države (Macan,1992, 393; Pavličević, 2000, 345-346; Szabo-Labus, 2012, 255-256).

Bitna obilježja nove države Kraljevine SHS potvrđena su daljnjim protezanjem srbijanskih zakona na cijelu zemlju, na kulturu i prosvjetu, školstvo i gospodarstvo. Primjerice, u Srbiji su bili niži porezi nego u Hrvatskoj, a njezina privredna poduzeća dobivala su unosnije narudžbe i koncesije za izvoz, veće dijelove inozemnih zajmova i dr. Visoka činovnička mjesta dobivali su isključivo Srbi, koje je i u Hrvatskoj postavljala središnja uprava u Beogradu (Pavličević, 2000, 337-338). Osobitu moć i utjecaj dobila je Srpska pravoslavna crkva, što se je pokazalo i kada je došlo u pitanje sklapanje konkordata sa Svetom Stolicom. 
Zbog političkoga otpora ubrzo su počeli progoni svih protivničkih političkih stranaka. Zbog snažnijega pozicioniranja svojega programa, Radićeva je stranka još 1920. promijenila ime u Hrvatska republikanska seljačka stranka (HRSS) te postala najjača stranka u Hrvatskoj. Djelovanje Radićeve stranke podupirala je i udruga Hrvatska žena, koju je u Zagrebu 1921. utemeljila književnica Marija Kumičić. I ona, kao i spomenuta udruga, bile su često progonjene, a djelovanje zabranjivano (Szabo, 2002).

\subsection{Prema ukidanju ustava}

Da bi internacionalizirao težak politički položaj hrvatskoga naroda, Radić je putovao i u inozemstvo (1923.-1924.), u London, Beč i Moskvu, gdje je HRSS učlanio u Treću Internacionalu (1924.), ali nije mnogo postigao. Zbog toga, kao i pokazivanja animoziteta prema Katoličkoj crkvi od strane nekih članova stranke, osobito prema svećenstvu, ona je izgubila na ugledu kod dijela svojih članova, ali se uspijevala konsolidirati, te su joj uz seljaštvo pristupili i drugi slojevi građanstva. Radić se je vratio u Hrvatsku u kolovozu 1924., a u veljači 1925. godine uhićen je u zgradi Seljačkoga doma u Zagrebu. Nakon što je 25. ožujka 1925. Pavle Radić, nećak Stjepana, pročitao u ime HRSS-a izjavu kojom se priznaje dinastija Karađorđevića i Vidovdanski ustav, Stjepan Radić pušten je iz zatvora. Tada je HRSS promijenio ime u Hrvatska seljačka stranka (HSS). Iste godine sastavljena je s radikalima Pašić-Radićeva koalicija i vlada "narodnoga sporazuma", u kojoj je Stjepan Radić od studenoga 1925. bio ministar prosvjete, a manji broj članova HSS-a ušao je u vladu kao ministri bez portfelja. Istovremeno je Svetozar Pribičević, raniji Radićev protivnik, promijenio svoja unitaristička stajališta i sve otvorenije zagovarao federalizam kao rješenje za sva politička pitanja i nepravde. U takvim okolnostima Radić i njegova stranka (HSS) u veljači 1927. napustili su koaliciju s Pašićevim radikalima, s kojima su ionako imali neprirodnu koaliciju te su prešli u oporbu. Radić je i dalje tražio da Kraljevina SHS bude savez država ili konfederacija, uz priznavanje hrvatske narodne posebnosti, te političke i građanske slobode, kao uvjet za demokraciju i trajni mir. Želeći učvrstiti svoje političke pozicije, Radić je prihvatio suradnju s Pribičevićevom Samostalnom demokratskom strankom (SDS). Još iste godine, u studenom 1927. sklopljena je Seljačko-demokratska koalicija (SDK) kao zajednička oporba beogradskomu režimu (Pavličević, 2000, 354-356).

Budući da radikalski zastupnici nisu više imali većinu u narodnoj skupštini, počeli su prijetiti ubojstvima HSS-ovim zastupnicima. Prijetnje su kulminirale 20. lipnja 1928. godine, kada je radikalski zastupnik Puniša Račić izveo atentat na Stjepana Radića i hrvatske zastupnike. Smrtno su ranjena dva hrvatska zastupnika. Dvojica su preživjela ranjavanja, a teško ranjeni Stjepan Radić umro je u Zagrebu 8. kolovoza 1928. godine. Radićeva smrt i veliki sprovod u Zagrebu značili su skori kraj vidovdanskoga poretka (Macan, 1992, 396). Na Radićevo mjesto izabran je Vlatko Maček, koji je slijedio politiku SDK. Zbog žestokih stranačkih sukoba, kralj Aleksandar već je početkom sljedeće godine 6. siječnja 
1929. proglasio diktaturu, nazvanu Šestosiječanjskom, kojom je ukinuo ustav i raspustio narodnu skupštinu.

Prije nego što istaknem bitne značajke Šestosiječanjske diktature i događaja koji su upravo munjevito slijedili, ističem da se u međuvremenu, tijekom 1925. javno slavila diljem Hrvatske, ali i Bosne i Hercegovine, 1000. obljetnica Hrvatskoga kraljevstva, odnosno vladanja kralja Tomislava (925.-1925.). Ona dobro ilustrira raspoloženje gotovo cijeloga naroda, i vjersko i političko, ali i barem neka obilježja kulture, kao i sudjelovanje žena u javnom životu. Stoga donosim kraći osvrt na tu proslavu i značenje.

\section{Proslava tisućite obljetnice Hrvatskoga kraljevstva (925.-1925.)}

\subsection{Obilježja i sadržaji proslave te uloga Hrvatske žene}

Važnu povijesnu obljetnicu na spomen vladanja kralja Tomislava (925.1925.) prihvatila su Radićeva HSS, Katolička crkva u Hrvatskoj i brojne građanske udruge, a time i široki slojevi naroda, jer je Tomislav surađivao s papom Ivanom X. Ovdje se ne želim upuštati u osporavanja kralja Tomislava zajedno sa spomenutom obljetnicom, koja od strane nekih povjesničara nisu prevladana ni danas. Ipak, ostaje neosporna činjenica da je sveopća proslava, premda nije bila jedinstvena, ipak bila i ostala javni odgovor hrvatskoga naroda režimu, kojim je bio nezadovoljan, i politikom nametnute i unitarne države.

Odlukom hrvatskih biskupa slavila se Tomislavova obljetnica sv. misama u Hrvatskoj i katoličkim crkvama u Bosni i Hercegovini. U cijeloj zemlji podizane su spomen-ploče u čast znamenitih ljudi, a za gradnju spomen-bazilike u Tomislavgradu u čast sv. apostola Ćirila i Metoda znameniti financijski prilog darovao je i papa Pio XI. (Pavličević, 2000, 351-352; Szabo, 2002, 89-90).

Tijekom proslave 1000. obljetnice Hrvatskoga kraljevstva istaknute članice Hrvatske žene održale su niz javnih predavanja širom Hrvatske, ali i Bosne i Hercegovine. Sudjelovale su i u radu oko realizacije reprezentativne Kulturno-historijske izložbe grada Zagreba, koja je također priređena u čast spomenute obljetnice Hrvatskoga kraljevstva, o čemu svjedoči i reprezentativni katalog Kuturnohistorijska izložba grada Zagreba (Zagreb, 1925.), koji je priredio Stjepan Srkulj, bivši gradonačelnik grada Zagreba (Srkulj, 1925, 8 i 130; Szabo, 2002, 89-90).

Članice Hrvatske žene sudjelovale su i u radu uredništva i pisanju članaka u poznatom zborniku Znameniti i zaslužni Hrvati 925-1925, koji je iste godine tiskan u Zagrebu. Uz to, Marija Kumičić uspjela je uz pomoć domaćih darovatelja i američkih Hrvatica, članica Hrvatske žene, obnoviti crkvu i Križni put na Ksaveru u Zagrebu s napisima muke Isusove i događaja iz hrvatske povijesti (Szabo, 2002, 92). Dvije posljednje postaje Križnoga puta uređene su i dobile svoje napise 2010. godine. Jedna je posvećena stradalnicima Drugoga svjetskoga rata, Bleiburga, križnih putova i podsljemenskih masovnih grobnica, a druga brojnim žrtvama za slobodnu hrvatsku državu u obrambenom Domovinskom ratu (1991.-1995.). 


\subsection{Dva glavna hrvatska hodočašća u Rim}

Tijekom proslave tisućite obljetnice Hrvatskoga kraljevstva organizirana su, uz brojna manja vjernička hodočašća, i dva glavna hodočašća u Rim. Zagrebački nadbiskup Antun Bauer predvodio je 1925. hrvatsko nacionalno hodočašće u Rim povodom spomenute 1000. obljetnice Hrvatskoga kraljevstva i vladanja kralja Tomislava. Tom prigodom nadbiskup Bauer darovao je papi Piju XI. zlatni kalež urešen grbovima Hrvatske, Slavonije, Dalmacije, Bosne i Hercegovine, a urezani su likovi sv. braće Ćirila i Metoda i hrvatskih blaženika Nikole Tavelića i Marka Križevčanina. Poruka je jasna! (Milić, 1998, 267).

Iste godine (1925.) i Ivan Merz, osnivač Hrvatskoga orlovskoga saveza (1923.), vodio je stotinu mladih Orlova u Rim na međunarodno hodočašće. Tom prigodom papa Pio XI. primio ih je u posebnu audijenciju i izrekao im u podužem govoru ove riječi: »U ovoj Svetoj jubilejskoj godini eto već po drugi put dolaze ovamo naši dragi sinovi iz Hrvatske da proslave s nama i svoj veliki povijesni jubilej kao spomen na onaj dan kad je Naš predšasnik papa Ivan X. podigao Hrvatsku na kraljevstvo. Stoga godinu 1925. slave Hrvati kao 1000. obljetnicu kraljevstva. Veselimo se stoga da vas vidimo, pozdravimo i blagoslovimo ovdje u očinskoj kući. «Iduće godine (1926.) Merz je sa šibenskim biskupom Jerolimom Miletom poveo na hodočašće u Rim veću skupinu djevojaka Orlica. I one su bile primljene u audijenciju kod Pape (Deželić ml., 2011, 1067-1069).

Hrvatski orlovski savez (HOS) bio je katolička organizaciju za mladež koju je Ivan Merz postavio na temelje Katoličke akcije ustanovljene od pape Pija XI. Njihov je aktivni član prije odlaska na teološke studije u Rim (1924.) bio i Alojzije Stepinac, koji je po povratku u Zagreb (1931.) osobito radio na jačanju Katoličke akcije u Hrvatskoj. Što je Merz značio za hrvatsku mladež i orlovsku organizaciju najbolje su izrazili sami mladi kad su mu nakon smrti (1928.) donijeli na grob vijenac s bijelom svilenom vrpcom na kojoj je pisalo: »Hvala ti Orle Kristov, što si nam pokazao put k suncu! « Merčeve, a time i orlovske ideale: Žrtva, Euharistija, Apostolat, preporučio nam je i sv. otac Ivan Pavao II. kad je proglasio Merza blaženim u Banjoj Luci 2003. godine (Šanjek, 1996, 435-436; Nagy, 2011, 466-468).

\section{4. Šestosiječanjska diktatura — Kraljevina Jugoslavija — uzroci sloma}

\subsection{Ukidanje ustava}

Kao što je spomenuto, zbog žestokih stranačkih sukoba, kralj Aleksandar 6. siječnja 1929. proglasio je diktaturu, kojom je ukinuo ustav, raspustio Narodnu skupštinu, zabranio rad svih političkih stranaka i sindikata, političke skupove i nacionalne simbole, građanska i vjerska udruženja s nacionalnim predznakom ili imenom, uveo cenzuru, proglasio ideologiju "integralnoga jugoslavenstva". Glavni oslonac nametnutoga poretka bili su vojska, žandari, uzak krug srpskih političara i državni službenici. 
Diktatura je uzrokovala teška nasilja i zastrašivanja, među kojima je i okrutni napad sa smrtnim posljedicama na hrvatskoga znanstvenika i domoljuba Milana Šufflaya ispred kućnoga praga u Zagrebu (1931.). Zbog Šufflayeva znanstvenoga ugleda njegovo je ubojstvo izazvalo velike proteste u svijetu, pa su, između ostalih, i znanstvenik Albert Einstein i književnik Heinrich Mann preko Međunarodne lige za prava čovjeka pozvali svjetsku javnost na prosvjed zbog toga zločina. Diktatura je potaknula organiziranje nacionalističkih i separatističkih građana u skupinu koja se je nazvala ustašama, i u Italiji se okupljala oko izbjegloga Ante Pavelića, do tada zastupnika Hrvatskoga bloka u skupštini u Beogradu (Pavličević, 2000, 365-366).

\subsection{Kraljevina Jugoslavija, progoni, položaj građanskih $i$ vjerskih udruga}

Novim ukazom kralja Aleksandra od 3. listopada 1929. država je umjesto dotadašnjega imena Kraljevina SHS dobila novo unitarno ime Kraljevina Jugoslavija, i taj je naziv zadržala do sloma (1941.). Novu državu kralj je nasuprot povijesnim posebnostima upravno podijelio na devet banovina, a njihove granice određene su tako da je u šest banovina osigurana većina srpskoga stanovništva.

Pooštreni su i zakoni protiv komunista i nacionalnih stranaka, zadržana cenzura, uveden Sud za zaštitu države, koji je mnoge osudio na zatvor i tamnicu, a bilo je i više smaknutih građana (Macan, 1992, 396). Te i druge zatvore posjećivali su i katolički svećenici. U Zagrebu osobito isusovac Josip Müller, tada i voditelj Marijinih kongregacija, te s njima i graditelj crkve u čast Kraljice Hrvata na zagrebačkoj gori Medvednici ili Sljemenu (Miklobušec, 2016, 27-31).

Vlada generala Živkovića nekim građanskim društvima s nacionalnim imenom nudila je njihovu obnovu s jugoslavenskim imenom, što je većina odbila. Tako je primjerice Hrvatskomu sokolskomu savezu ponuđeno članstvo u Jugoslavenskom sokolu, što su oni odbili. Savezu hrvatskih učitelja ponuđen je ulazak u Jugoslavenski savez učitelja, što je njegov predsjednik Milutin Mayer također odbio. Zato je ostao bez posla, kao i mnogi drugi učitelji i profesori. Među njima i poznati arheolog don Frane Bulić, koji je odbio i ponuđeni mu razgovor s kraljem.

I Hrvatski orlovski savez zbog nacionalnoga predznaka našao se na meti režima, i stoga je već sljedeće godine 1930. promijenio ime u Križarsko bratstvo za odrasle, a za mladež u Mali križari, te nastavio djelovati na temeljima Katoličke akcije i Merčevih ideala. Druge katoličke udruge i glasila, koja nisu imala nacionalne predznake, među njima i filozofsko-teološki časopis Život, nastavili su svoje djelatnosti. Jednako i sve crkvene ustanove, katoličke, pravoslavne, židovske i druge. Također njihove škole, domovi, bolnice i druge ustanove (Šanjek, 1996, 470-474; Miklobušec, 2016, 36-44).

\subsection{Svjetska gospodarska kriza, povratak ustava, Zagrebačke punktacije}

Godine 1929. izbila je velika svjetska gospodarska kriza, ili velika depresija, najprije u SAD-u, te je između godine 1931. i 1933. zahvatila i europske zemlje. 
Potrajala je do izbijanja Drugoga svjetskoga rata, koji je na svoj način i uzrokovala. Od 1931. sve snažnije pokucala je i na vrata unitarne Jugoslavije. Hrvatska je 30-ih godina još uvijek bila pretežito agrarna zemlja, jer se $75 \%$ stanovništva bavilo poljoprivredom. Vrlo niska razina investicija odrazila se je na zaostajanje hrvatskoga sela, a prijeko potrebna agrarna politika, kojom bi se riješio ranije započeti proces agrarne reforme, u biti nije ni postojala. Zbog nestašice kredita obustavljeni su melioracijski radovi, a i komasacija nije bila provedena. U takvim uvjetima mnoga hrvatska seljačka gospodarstva i dalje su zadržala obilježja autarkije. Uz to veliki su problemi bili stanje i položaj radnika. Sve više ljudi ostajalo je bez posla, a time i bez sredstava za život. Dodatno slamanje hrvatskoga gospodarstva prouzročilo je i preseljenje financijskoga središta iz Zagreba u Beograd (Pavličević, 2000, 391-393).

U takvim okolnostima Dvor je odlučio vratiti ustav, koji je nazvan Rujanskim ustavom (1931.). Budući da ga nije donijela narodna skupština, nazvan je nametnutim ili oktroiranim. I njegova su obilježja apsolutizam i centralizam: kralj je i dalje imao apsolutnu vlast, a nisu osigurane ni političke slobode. Zato je vodstvo Seljačke demokratske koalicije (SDK) proglasilo politički program poznat pod nazivom Zagrebačke punktacije (1932.). Program je izradio Ante Trumbić, a prihvatile su ga sve hrvatske stranke. Njegova je bit: demokracija, federalizam, narodni suverenitet, osuda srbijanske hegemonije i šestosiječanjskoga apsolutizma te zahtjev povratka na stanje godine 1918. kao bitno polazište za pregovore o rješavanju svih nagomilanih političkih i društvenih pitanja. Budući da je Maček supotpisao Punktacije i svoja stajališta objavio u stranim novinama početkom sljedeće godine (1933.), Sud za zaštitu države osudio je Mačeka na trogodišnju zatvorsku kaznu, ali je zbog bolesti u prosincu 1934. ukazom Namjesništva amnestiran te je nastavio političko djelovanje (Macan, 1992, 398-399; Szabo-Labus, 2012, 262-263).

\section{Urušavanje unitarizma i centralizma - osnove federativne države}

\subsection{Smrt kralja Aleksandra, vladanje namjesništva}

S porastom nacizma u Njemačkoj nakon 1933. godine jugoslavenska se je politika počela zbližavati s Hitlerom. Na to je Francuska oštro reagirala te je godine 1934. pozvala kralja Aleksandra u državnički posjet. Kralj se nadao da će pod zaštitom Francuske ojačati međunarodni položaj Jugoslavije, ali je ubijen u Marseilleu 9. listopada 1934. (Macan, 1992, 400).

Od tada je prema kraljevoj oporuci Kraljevinom Jugoslavijom u ime maloljetnoga kralja Petra II. vladalo tročlano kraljevsko namjesništvo: knez Pavle Karađorđević, njegov bratić Radenko Stanković te senator, dvorski liječnik i ban Savske banovine Ivo Perović (Szabo-Labus, 2012, 266).

Središnji nositelj vlasti knez Pavle dopustio je provođenje izbora, ali nije ukinuo ustav (oktroirani). Beogradska vlada nastavila je progoniti komuniste i federaliste, također i udruženu opoziciju, koju je vodio Vlatko Maček. I u takvim 
uvjetima Maček je užurbano radio na rješenju "hrvatskoga pitanja", odnosno pravednoga položaja Hrvatske unutar Jugoslavije, tim više što su Njemačka i Italija prijetile Europi ratom. Zato je Maček želio jačanje Jugoslavije i razbijanje njezine izolacije u inozemstvu, i nikada nije želio stati uz Njemačku. Javno je tvrdio da je »zadovoljna Hrvatska što i snažna jugoslavenska država«. Surađivao je s opozicijskim strankama u Srbiji, pregovarao s knezom Pavlom, koji je bio sklon kompromisu, zagovarao federalizam i tražio da se odredi teritorij i prava Hrvatske. Nakon otpora radikalskoga predsjednika vlade Milana Stojadinovića Maček je nastavio pregovore s novim predsjednikom Dragišom Cvetkovićem. Konačno su uoči početka Drugoga svjetskoga rata uspjeli potpisali tzv. sporazum Cvetković-Maček (26. kolovoza 1939.), kojim je osnovana Banovina Hrvatska kao zasebna teritorijalna jedinica unutar Kraljevine Jugoslavije (Macan, 1992, 400; Szabo-Labus, 2012, 266-267).

\subsection{Banovina Hrvatska}

Osnivanjem Banovine Hrvatske znatno je narušen jugoslavenski centralizam i unitarizam. Postavljene su osnove federativne jugoslavenske države u kojoj je Banovina Hrvatska imala status federalne jedinice sve do skoroga raspada Jugoslavije u travnju 1941. godine. U sastav Banovine, kojoj je na čelu bio ban Ivan Šubašić, ušle su savska i primorska banovina te kotarevi Dubrovnik, Ilok, Šid, Brčko, Gradačac, Derventa, Fojnica, Travnik, dakle najveći dio područja Kraljevine Jugoslavije s većinskim hrvatskim pučanstvom. Izuzetak su bila sjeverna jadranska područja koja su Rapalskim ugovorom (1920.) pripala Italiji. Većina članova HSS-a prihvatila je taj sporazum kao privremeno rješenje, ali je bilo u stranci i izvan nje glasnih protivnika. U Hrvatskoj su komunisti govorili da sporazum nije demokratski i da je njime Hrvatska prodana Beogradu. S druge strane, srpske su stranke govorile kako je Hrvatima dano previše, te izbacile krilaticu "Srbi na okup", koja je ponavljana i u vrijeme priprema za stvaranje moderne Hrvatske, kao i Domovinskoga rata (1990.-1995.). Srbi su se htjeli izdvojiti iz Banovine Hrvatske. Slično je bilo i u Bosni, a tamošnji Srbi htjeli su uključiti Bosnu i Hercegovinu u srpsku državnu jedinicu (Macan, 1992, 400-401; Szabo-Labus, 2012, 265-268).

Uspostavu Banovine Hrvatske prihvatilo je brojno građanstvo i nadbiskup Alojzije Stepinac te je čestitao Vlatku Mačeku. Ističem da je i Hrvatski ustav iz 1990. godine uključio uspostavu Banovine Hrvatske u izvorišne osnove hrvatske državnosti. Ustav izrijekom navodi da je uspostavom Banovine Hrvatske obnovljena hrvatska državna samobitnost u Kraljevini Jugoslaviji.

\section{Položaj i djelovanje Katoličke crkve}

\subsection{Osnivanje Karitasa, Katolička akcija, pitanje konkordata}

U spomenutim socijalnim okolnostima zagrebački nadbiskup Antun Bauer, na poticaj okružnice pape Pija XI. Caritate Christi compulsi (1931.), osnovao 
je krajem iste godine Dijecezanski Caritas. Učinio je to i na prijedlog Alojzija Stepinca, koji se je te godine vratio iz Rima u Zagreb i stavio nadbiskupu na raspolaganje. Vodstvo Caritasa uskoro je u cijelosti bilo povjereno upravo njemu. Stepinac je preuzeo i vodstvo Katoličke akcije (1934.), te tako uskoro postao nova zvijezda na obzorju Crkve u Hrvata. Bit je Katoličke akcije sudjelovanje laika u poslanju Crkve: u radu Caritasa, širenju katoličkoga tiska, javna hodočašća vjernika, angažiranje u gradnji crkava i dr. Stoga njezini članovi ne sudjeluju u sindikatima, političkim strankama i slično (Šanjek, 1996, 438-439).

Na poticaj prorežimskoga društva Sokol Kraljevine Jugoslavije, zagrebački mason Oto Gavrančić, pravnik i poslanik u Narodnoj skupštini u Beogradu, izradio je Prijedlog zakona o izgonu isusovaca iz Jugoslavije na otok Vis, i za crkvene redove koji su bili bliski isusovcima, ili su surađivali s njima. Uz veći broj supotpisnika 4. veljače 1933. podnio ga je skupštini. Zbog protivljenja katoličke javnosti u Zagrebu, ali i diljem Hrvatske, te molitava i procesija osobito u čast Blažene Djevice Marije, brojnih protesta upućenih kralju i zauzimanja nadbiskupa Antuna Bauera, taj zakon nije nikada razmatran u skupštini (Miklobušec, 2016, 361-367).

Među problemima Katoličke crkve ističu se dugotrajni i teški pregovori oko potpisivanja konkordata sa Svetom Stolicom, koji su započeli 1929. godine, i na kraju nisu uspjeli. Načinjen je ugovor o konkordatu 1935. i potpisan u Rimu dvije godine poslije, 1937., te izglasan u Narodnoj skupštini u Beogradu sa 166 glasova za i 129 protiv, ali ipak nije potpisan od strane Jugoslavije. Zbog žestokoga protivljenja Srpske pravoslavne crkve, koja je izrekla crkvene kazne protiv zastupnika koji su glasali za konkordat, i krvavih uličnih prosvjeda u Beogradu (Krvava litija), vlada je odustala predložiti ga Senatu na ratifikaciju (Šanjek, 1996, 448-449). Razumije se, takav postupak imao je negativan odjek u hrvatskoj javnosti, ali i svijetu.

\subsection{Sveta godina 1933. — gradnja crkvi — radosni i teški trenutci}

Papa Pio XI. proglasio je godinu 1933. Izvanrednom svetom godinom otkupljenja na spomen 1900. obljetnice Isusove smrti na križu i slavnoga Uskrsnuća. I te Svete godine hrvatski su vjernici hodočastili u Rim, također trpjeli i iskušenja, a na njezin spomen gradili su i crkve u Hrvatskoj i izvan nje.

Među više hodočašća tijekom Svete godine ističem hrvatske hodočasnike, njih 350, koji su boravili u Rimu od 22. do 31. svibnja 1933. i pod vodstvom dvojice katoličkih laika, Velimira Deželića ml. i Stjepana Markulina. Prigodom svečane audijencije kod pape Pija XI., 24. svibnja 1933. Deželić je papi uručio Spomenicu u kojoj su upisani glavni događaji iz hrvatske povijesti na latinskom i hrvatskom jeziku, koji svjedoče o prijateljstvu i vjernosti Hrvata sa Svetom Stolicom. Tekst Spomenice sastavili su na latinskom i hrvatskom jeziku don Frane Bulić i prof. Lovro Katić, a umjetnički vrlo ukusno opremila likovna umjetnica Olga Höcker. Papa je kratko pogledao tekst Spomenice, a potom održao govor, koji je zaključio riječima: »Neka Gospodin otkupljenja usliša našu molitvu i neka ove Svete godine oslobodi cijeli svijet, a osobito one krajeve koji su više iskušavani, i više 
trpe, kao i našu dragu Hrvatsku. « Papin govor objavio je časopis Hrvatska straža, ali su ga odmah zaplijenile jugoslavenske vlasti pod optužbom da papin govor nije valjano preveden, a urednici su morali na sud. Tim više što je L'Osservatore Romano objavio samo odabrane odlomke iz spomenutoga govora Svetoga Oca (Deželić ml., 2011, 1149-1151).

Ta je Sveta godina (1933.), uz gradnju i posvetu crkve u čast Kraljice Hrvata na zagrebačkoj gori Medvednici, koju je gradnju uz pomoć brojnih darovatelja vodio isusovac p. Josip Müller i posvetio zagrebački nadbiskup Antun Bauer (1933.), potaknula i gradnju crkvi izvan Zagreba (Miklobušec, 2016, 27-30). Među njima ističem gradnju crkve u čast sv. Petra u Beogradu, koju su uz mnogo muka i osporavanja lokalnih vlasti dovršili isusovci iste godine (1933.), i koju oni kao župnu crkvu vode i danas. Budući da su u međuvremenu isusovci došli u Osijek (1930.), ljubljanski arhitekt Jože Plečnik projektirao je planove Svetišta u čast Srca Isusova, koji su konačno odobreni od nadležnih vlasti (1938.). Zbog ratnih opasnosti gradnja crkve na Gajevu trgu u Osijeku (danas Gradska tržnica) započela je tek u listopadu 1940. godine. Do kraja rata podignuti su temelji crkve i kripta te zidovi do 7 metara visine. Nedovršenu crkvu komunističke su vlasti srušile 1948. (Miklobušec, 2016, 255-263). Krajem 2018. na tom je mjestu nastojanjem vjernika postavljena ploča s vrijednim podatcima o povijesti Svetišta Srca Isusova u parku na spomenutom trgu u Osijeku.

\section{Drugi svjetski rat i njegove posljedice}

\subsection{Slom Kraljevine Jugoslavije — neposredni uzroci}

Kraljevina Jugoslavija pristupila je 25. ožujka 1941. Trojnomu paktu tada nacističke Njemačke, fašističke Italije i militarističkoga Japana te više manjih europskih država. Potpisali su ga u Beču predstavnici jugoslavenske vlade Cvetković i Maček. Dva dana poslije, u Beogradu su 26. i 27. ožujka, i to na pritisak zapadne diplomacije, koja je željela Jugoslaviju imati na svojoj strani, održane demonstracije protiv takve odluke pod sloganom: "Bolje rat, nego pakt!" Vojni zavjerenici i dio političara, iza kojih je stajala Velika Britanija, svrgnuli su Kraljevsko namjesništvo na čelu s knezom Pavlom, proglasili punoljetnim Petra II. Karađorđevića, koji se je već nalazio u izbjeglištvu u Londonu, a vlast u Jugoslaviji preuzela je vlada generala Dušana Simovića. Ogorčen time što mu je propao planirani napad na Rusiju, Hitler je bez najave rata 6. travnja 1941. napao Jugoslaviju, koja je ubrzo kapitulirala 17. travnja 1941. Dva dana prije, 15. travnja 1941. ban Ivan Šubašić zajedno s predsjednikom vlade generalom Simovićem napustio je zemlju te su otišli u London. Time je prestala postojati i Banovina Hrvatska (Macan, 1992, 401-402).

\subsection{Nezavisna Država Hrvatska}

Budući da je Vlatko Maček odbio ponudu Nijemaca da on proglasi hrvatsku državu unutar osovinskoga sustava, Nijemci su se okrenuli Anti Paveliću, koji 
se je nalazio u emigraciji u Italiji, pa je, u dogovoru s njim i prije njegova dolaska u Zagreb, pukovnik Slavko Kvaternik proglasio na Radio Zagrebu uspostavu Nezavisne Države Hrvatske (10. travnja 1941.). Njemačke motorizirane jedinice ušle su u Zagreb, i od jednoga dijela građana dočekane su na ulicama grada i cvijećem. Sve institucije Banovine Hrvatske, i to na javnu preporuku Vlatka Mačeka, stavile su se na raspolaganje novouspostavljenoj državi, ali ne zbog pristajanja uz osovinsku ideologiju, nego zbog želje za svojom hrvatskom državom, i jer nisu željeli živjeti u Jugoslaviji (Pavličević, 2000, 401-403).

Pavelić se je vratio u Hrvatsku uz talijansku pomoć te je uz pristanak Njemačke stigao u Zagreb 14. travnja 1941. godine. Sutradan 15. travnja objavio je da je u svoje ruke preuzeo vlast u NDH. Imenovao je prvu državnu vladu (16. travnja 1941.), koju su istoga dana priznale Njemačka i Italija, a uskoro i druge zemlje članice Osovine. NDH je dva mjeseca poslije, 15. lipnja 1941. potpisala Trojni pakt (Pavličević, 2000, 403 i 405).

Mjesec dana poslije Pavelić je putovao u Rim te ga je primio u privatni posjet papa Pio XII. (18. svibnja 1941.), premda Sveta Stolica nije nikada priznala NDH. Za boravka u Rimu Pavelić je bio primoran potpisati ponižavajuće Rimske ugovore (20. svibnja 1941.), kojima je Hrvatskoj bio oduzet znatan dio njezine obale u korist Italije, što je izazvalo veliko nezadovoljstvo u narodu. U takvim okolnostima komunisti su mjesec dana poslije u šumi Brezovica kod Siska osnovali prvi sisački partizanski odred (22. lipnja 1941.), ali zbog istovremenoga Hitlerova napada na SSSR, oni tada nisu započeli ustanak (Pavličević, 2000, 405-406).

Državna politika NDH od samoga je početka uvelike ovisila o odlukama Njemačke i Italije kao vojno-političkih pokrovitelja, a time i uvođenje rasnih zakona. Tim potonjim postupcima od samoga se je početka i sve do sloma NDH, koji je vezan uz slom nacističke Njemačke (1945.), glasno protivio zagrebački nadbiskup Alojzije Stepinac. Protivio se je "rasnim zakonima”, a vlastima NDH napisao je brojna pisma i upućivao javne prigovore. Ljudska prava i slobode, te zaštita progonjenih, "jer su svi ljudi djeca Božja” bila je stalna tema njegovih propovijedi i svih njegovih nastojanja. Neumorno je osuđivao sva nasilja, također u pitanjima "prelaska na katolicizam". Riječju, ali i djelima ustrajno je štitio i spašavao Židove i Srbe, razumije se i Hrvate nepravedno progonjene, među kojima se našao i Ivan Meštrović, Jozo Kljaković i mnogi drugi (Šanjek, 1996, 454-455; 460-468; Batelja, 2000; Batelja, 2012).

U proljeće 1945. ubrzano se približavao slom Njemačke, a time i slom NDH, kraj Drugoga svjetskoga rata i ulazak partizana u Zagreb 8. svibnja 1945. godine. Ti događaji više nisu tema ovoga rada. Daljnja tema odnosi se na godinu 1971. i promjene koje su slijedile. 


\section{Na putu prema promjenama 1971.-1989.}

\subsection{Značenje 1971. godine, Tito kod pape, olakšan položaj vjernika}

Godinu 1971. bitna je kako zbog burnih događaja koji su slijedili, također na vjerskom planu, i time je utirala put političkim promjenama. Tu je uzeta kao polazište jer je te godine, kako je i spomenuto, ponovno počeo izlaziti u Zagrebu časopis Život, ali sada pod naslovom Obnovljeni Život, jer su se u međuvremenu već pojavili časopisi s njegovim prvotnim naslovom.

Zahvaljujući već ranije započetim promjenama u svijetu, osobito u pogledu dijaloga s drugima i drugačijima, koje je vrijednosti promovirao i Drugi vatikanski sabor, 29. ožujka 1971. održan je službeni susret šefa socijalističke države Jugoslavije Josipa Broza Tita i pape Pavla VI., suverena vatikanske države i poglavara Katoličke crkve. Značenje toga susreta potvrđuje i činjenica da je razgovor Pavla VI. i Tita trajao 75 minuta, što je bilo više negoli s bilo kojim državnikom koji je do tada bio u Vatikanu. Bio je to nakon 1945. i prvi posjet predsjednika jedne socijalističke zemlje Svetoj Stolici, koji je došao Vatikan (Šanjek, 1996, 478; Milić, 1998, 277).

Bilo je i javnih nezadovoljstva odlaskom Tita u Vatikan, i to zbog njegovih ranijih postupaka, kao što su Bleiburg, križni putovi, teški progoni Katoličke crkve, među kojima je i politički montirani sudski postupak protiv kardinala Stepinca. Ipak, bilo je to ozračje Drugoga vatikanskoga sabora, i mnogo je važnije što trajni plodovi toga susreta nisu izostali. U Hrvatskoj su se, uz izlaženje više katoličkih glasila, počele postupno osnivati nove župe i crkve, ponajprije u privatnim kućama, ali i s određenim teškoćama od nekih političkih moćnika (Šanjek, 1996, 478-480).

S druge pak strane, već u proljeće 1971. ojačao je i pokret hrvatskih sveučilištaraca, koji su preuzeli vodstvo Saveza studenata na Zagrebačkom sveučilištu. Matica hrvatska širokim okupljanjem svojega članstva diljem Hrvatske i u hrvatskom iseljeništvu izrasla je u najveću opozicijsku snagu u borbi za suverenost hrvatskoga naroda i hrvatske države. Njezina glasila Kolo, Hrvatski tjednik i dr. pisala su kako centralizam i navodna solidarnost ide u prilog Srbije te da je očit nerazmjer ulaganja u Hrvatsku i republičkih izdvajanja u saveznu blagajnu i prihoda od turizma, te su stoga tražili politiku "čistih računa". Krajem 1971. otvoreno se je kritizirao i težak položaj hrvatskoga naroda u Bosni i Hercegovini, neravnomjerna zastupljenost Hrvata u vodećim tijelima te jugoslavenske republike te se je naglašavala povijesna pripadnost Bosne i Hercegovine Hrvatskoj (Pavličević, 2000, 486-487).

Vrhunac hrvatskoga otpora bio je govor predsjednice CK SKH Savke Dabčević-Kučar 8. svibnja 1971. na Trgu Republike, danas Trgu bana Jelačića, pred 200.000 ljudi, koji su aklamacijom većine nazočnih odobravali njezine zahtjeve za reformama. Sve su glasniji bili i oni koji su se zalagali za potpunu neovisnost Hrvatske. U srpnju 1971. Tito je od vodstva u Hrvatskoj zatražio uhićenje istaknutih hrvatskih opozicionara i smirivanje napetosti u Hrvatskoj. Stoga su zagrebački studenti radikalizirali situaciju velikim zborom 29. listopada iste godine, 
na kojem su tražili demokraciju i samostalnost Hrvatske, a prigovarali vodstvu Hrvatske da nije sposobno voditi nacionalni pokret hrvatskoga oslobođenja. Studentski štrajk u Zagrebu, Splitu i Zadru pod geslom "za hrvatske devize", uvjerio je Tita i CK SKJ da hitno treba nešto poduzeti za očuvanje Jugoslavije. Srbi u Hrvatskoj nisu podržavali studentske zahtjeve iz više razloga: zbog privilegiranoga položaja u državnim tijelima vlasti, zbog sjećanja na NDH i zbog napisa u Hrvatskom tjedniku kojima se naglašavao nedjeljiv suverenitet hrvatskog naroda u Hrvatskoj (Pavličević, 2000,488-491).

\subsection{Višestruki odgovori saveznih vlasti - ustav 1974.}

Na sjednici Predsjedništva SKJ, koja je održana u Karađorđevu 1. i 2. prosinca 1971., na koju je Tito pozvao 19 članova CK SKH, napadnuto je hrvatsko vodstvo, a u nastavku sjednice i tijekom sljedećih desetak dana prihvaćene su ostavke Savke Dabčević-Kučar, Mike Tripala i njihovih najužih suradnika.

U višim područjima vlasti u Hrvatskoj smijenjena je 741 osoba, 280 članova Partije prisiljeno je dati ostavku, 131 hrvatski dužnosnik degradiran je, a neki od vođa, među njima Franjo Tuđman i studentski vođe, morali su u zatvor. Zabranjen je i rad Matici hrvatskoj. Tijekom sljedećih dviju godina (1972.-1973.) u Hrvatskoj su provedeni brojni sudski politički procesi, tzv. čistke, u kojima su izrečene presude o krivnji optuženih za politička krivična djela. Žrtve su bili brojni Hrvati koji su optuženi da su politički djelovali na rušenju vladajućega poretka (Pavličević, 2000, 491).

Nastavljeni su i procesi nekih promjena. Njihov je vrhunac proglašenje novoga ustava SFRJ (21.veljače 1974.), koji je Jugoslaviju definirao kao »državnu zajednicu dobrovoljno ujedinjenih naroda s pravom na odcjepljenje, ako to bude volja republika, federalnih članica « koje su dobile veću neovisnost u odnosu na središnju vladu u Beogradu. Ojačan je suverenitet republika, koje su tretirane kao posebne države, i time se Jugoslavija približila konfederalizmu. Ustav je iskoristio 1990. predsjednik Franjo Tuđman za stvaranje slobodne i suverene hrvatske države s međunarodnim priznanjem (Pavličević, 2000, 493-494).

Ustav je zastupao načelo da se "socijalističko društveno-ekonomsko uređenje" zemlje temelji "na vlasti radničke klase i svih radnih ljudi” i dalje u osloncu na ideologiju marksizma. Uveden je sustav radničkoga samoupravljanja, koji je bio još jedan bezuspješan pokušaj prevladavanja društvene i gospodarske krize u koju je tonula Jugoslavija, osobito nakon Titove smrti (1980.). Galopirajuća inflacija, veliki inozemni dug pogoršan naglim skokom vrijednosti dolara, kao i monetarna nelikvidnost, dovodili su zemlju na rub propasti - do bankrota, a život građana bivao je sve teži (Pavličević, 2000, 495-497). Hrvatski narod i tada se, kao i više puta u svojoj povijesti, okrenuo duhovnoj obnovi, ali i Svetoj Stolici u Rimu. 


\subsection{Nacionalna proslava Trinaest stoljeća kršćanstva u Hrvata}

Kad je papa Pavao VI. proglasio Svetu godinu 1975. u znaku "pomirenja, obnove i mira”, ona je slavljena i u Hrvatskoj. Sljedeće godine, 12. rujna 1976. započela je u Solinu nacionalna proslava Trinaest stoljeća kršćanstva u Hrvata (641.-1941.), koju je ranije planirao nadbiskup Stepinac. Slavila se tada u Ninu i Tisućugodišnjica smrti kraljice Jelene (976.-1976.), koja je izgradila najstariju poznatu Gospinu crkvu na solinskom Otoku i crkvu svetoga Stjepana, mauzolej hrvatske kraljevske obitelji. Na proslavi je bio kardinal Franjo Šeper, koji je i predsjedao misnomu slavlju, te desetak kardinala, među kojima i bečki kardinal König, pariški Marty, mletački Luciani (kasniji papa Ivan Pavao I.), hrvatski biskupi, brojni svećenici i više od 100.000 vjernika. Nazočan je bio predstavnik Srpske pravoslavne crkve i Islamske zajednice u Hrvatskoj. Te proslave bile su uvod u proslavu Branimirove godine u Ninu (879.-1979.), i završnim Nacionalnim euharistijskim kongresom u Mariji Bistrici 1984. (Śanjek, 1996, 488-492; Milić, 1998, 278).

Tijekom proslave Branimirove godine (879.-1979.) više od deset tisuća Hrvata hodočastilo je u Rim na susret s Ivanom Pavlom II. Susret je upriličen 30. travnja 1979. na grobu sv. Petra. Tom je prigodom Sv. Otac, i to prvi puta u hrvatskoj povijesti, slavio misu i održao propovijed na hrvatskom jeziku. Iste godine održana je središnja proslava u Ninu 8. rujna 1979., na kojoj je bilo prisutno više od sto tisuća vjernika. Svoju naklonost papa je Hrvatima pokazao sljedećih godina, te osobito upisom zagrebačkoga nadbiskupa Franje Kuharića u zbor kardinala Rimske crkve i kanonizacijom hrvatskoga kapucina Leopolda Mandića (1983.), a poslije i drugim kanonizacijama (Milić, 1998, 278 i 283; Nagy, 2011, 51-59).

Povodom završetka proslave Trinaest stoljeća kršćanstva u Hrvata održan je Nacionalni euharistijski kongres (1984.) sa središnjom proslavom u Zagrebu (8. rujna), te u Mariji Bistrici (9. rujna). Premda su ga vlasti ometale, na proslavi se je okupilo 400.000 vjernika. Na kongresu su bili prisutni predstavnici Srpske pravoslavne crkve i ostalih vjerskih zajednica u Hrvatskoj (Nagy, 2011, 87-92). Mnogi sudionici tih svečanosti, ali i kasniji komentatori, ocijenili su da su one, uz duhovnu obnovu naroda, također nagovijestile i nadu u neodrživost jugoslavenskoga režima, što se je uskoro i dogodilo.

\section{Hrvatska na putu prema suverenosti}

\subsection{Višestranački izbori, novi ustav, međunarodno priznanje}

Novi papa Ivan Pavao II. za svojega pontifikata (1978.-2005.) bitno je pridonio dubokim promjenama u svijetu, osobito u Europi, koje je najavio i pad Berlinskog zida (9./10. studenoga 1989.), time i komunizma u europskim zemljama, i kod nas u Hrvatskoj.

U takvim okolnostima Sabor SR Hrvatske donio je Zakon o uvođenju višestranačja, (11. siječnja 1990.) te uskoro i novi izborni zakon koji je omogućio pro- 
vođenje višestranačkih izbora (14. veljače 1990.), koji su održani krajem travnja i početkom svibnja iste godine. Na njihovim temeljima održana je 30. svibnja 1990. prva sjednica Hrvatskoga sabora s demokratski izabranim zastupnicima, koji je izabrao Franju Tuđmana za predsjednika. Krajem srpnja Sabor je usvojio ustavne amandmane kojima Hrvatska prestaje biti "socijalistička", a umjesto zvijezde na zastavu je vraćen povijesni hrvatski grb.

Krajem iste 1990. Hrvatski sabor jednoglasnom odlukom donio je novi Ustav Republike Hrvatske, Njegova je bit parlamentarna demokracija, ljudska prava i slobode (Barunčić Pletikosić, 2017, 42-43). Ustav je doživio nekoliko dopuna, a posljednja je učinjena amandmanom na članak 61, kojim je određeno da je brak životna zajednica muškarca i žene (11. prosinca 2013.).

Budući da su hrvatski građani na referendumu 19. svibnja 1991. većinom od 94,17\% glasovali za samostalnu Hrvatsku, Hrvatski je sabor mjesec dana poslije, 25. lipnja 1991., izglasao i proglasio Deklaraciju o uspostavi suverene i samostalne države te pokrenuo postupak za razdruživanje od drugih republika SFRJ, i to na temelju ustava iz 1974., te poradio na međunarodnom priznanju Republike Hrvatske. Sutradan, 26. lipnja, Sabor je donio zakon o Hrvatskoj akademiji znanosti i umjetnosti, koja se više nije zvala "jugoslavenska". 8. listopada 1991. donio je odluku o raskidu svih državnopravnih sveza s republikama bivše SFRJ (Pavličević, 2000, 517-520). U međuvremenu je predsjednik Franjo Tuđman dva puta putovao u Rim i bio primljen u audijenciju kod pape Ivana Pavla II. (Šanjek, 1996, 509-510).

U daljnjim nastojanjima za međunarodno priznanje, a uskoro i za zakonitu obranu zemlje od velikosrpskoga agresora, osobitu moralnu pomoć Hrvatskoj pružila je Sveta Stolica, i osobno sv. otac Ivan Pavao II. Ponajprije time što je Sveta Stolica 13. siječnja 1992. priznala Hrvatsku, njezin suverenitet i samobitnost, te time potaknula svih 12 članica Europske unije, pa su i one dva dana poslije priznale samostalnost i suverenost Republike Hrvatske (15. siječnja 1992.). Hrvatsku je uskoro priznalo i četrdesetak drugih zemalja, također SAD, a potom i ostale zemlje svijeta. U članstvo UN-a primljena je Hrvatska 22. svibnja 1992. godine. Diplomatski odnosi između Svete Stolice i Republike Hrvatske uspostavljeni su 8.veljače 1992. (Šanjek, 1996, 511-512).

\subsection{Domovinski rat 1991.-1995.}

Na područjima Like i Dalmacije gdje su pripadnici manjinske srpske etničke zajednice imali većinu, oni pod utjecajem predsjednika Srbije Slobodana Miloševića nisu htjeli prihvatiti demokratske promjene u Hrvatskoj. Stoga su 17. kolovoza 1990. započeli oružanu pobunu, koja je uz progone hrvatskoga i drugoga nesrpskoga stanovništva uzrokovala i brojne ljuske žrtve. One su kulminirale padom Vukovara 18. studenoga 1991., usprkos višemjesečnoj nadljudskoj obrani grada. Stanovništvo grada odvođeno je pod nadzorom "jugovojske”, dio je netragom nestao, a ranjenici iz vukovarske bolnice brutalno su pogubljeni nedaleko grada, na Ovčari (Barunčić Pletikosić, 2017, 43-45). Od tada je nastavljen obrambeni Domovinski rat, nametnut od strane velikosrpskoga agresora, potpomognutoga 
iz Srbije. Od strane agresora rat je praćen brojnim razaranjima hrvatskih gradova, sela i sakralnih objekata te velikim ljudskim žrtvama, među kojima su i djeca, i progonima hrvatskoga pučanstva iz njihovih domova.

Premda i sama teško pogođena ratnim posljedicama, Hrvatska je godine 1993. zbrinjavala više od 253.000 prognanika i gotovo 400.000 izbjeglica, od kojih najveći dio iz Bosne i Hercegovine, a da pri pružanju utočišta nije pitala "ni za vjeru, ni za naciju”. Pomogle su joj u tom i humanitarne ustanove iz Europe i svijeta, te Hrvati iz iseljeništva, osobito iz SAD-a.

Budući da se Hrvatska morala spremati na konačno slamanje agresora, ona je uz povremene manje, ali i veće vojne uspjehe, na kraju pobjedonosnom Olujom (4.-7. kolovoza 1995.) oslobodila svoja zaposjednuta (okupirana) područja od kojih je agresor načinio tzv. SAO Krajinu sa sjedištem u Kninu. I uz Božju pomoć, kako je to često govorio i predsjednik Republike Franjo Tuđman. Budući da je hrvatska vojska oslobodila Knin 5. kolovoza 1995., na spomen te pobjede slavi se od tada svake godine u Republici Hrvatskoj Dan pobjede i domovinske zahvalnosti i Dan hrvatskih branitelja.

Budući da su srpske manjinske zajednice i unatoč garancijama hrvatskih vlasti za njihovu sigurnost, masovno napuštali oslobođena područja, Stalno vijeće Hrvatske biskupske konferencije 8 . kolovoza 1995. objavilo je posebnu izjavu iz koje je razvidno da to pučanstvo napušta svoje domove na izričit poziv Srpske pravoslavne crkve (biskup Longin) i po naredbi srbijanskoga generala Mile Mrkšića. Mirnom reintegracijom hrvatskoga Podunavlja, uključujući i grad Vukovar, i ta su područja vraćena u sastav Republike Hrvatske (15. siječnja 1998.).

\subsection{Pastirski pohodi dvojice papa Hrvatskoj — poticaji obnove naroda}

Poslije osamostaljenja i dobivanja međunarodnoga priznanja (1992.) te ulaskom Hrvatske u UN, papa Ivan Pavao II. pohodio je tri puta Republiku Hrvatsku. Prvi puta za vrijeme Domovinskoga rata, 10. i 11. rujna 1994. prigodom 900. obljetnice osnivanja Zagrebačke biskupije (1094.-1994.). Gruda hrvatske zemlje koju je Sv. Otac poljubio i blagoslovio u zračnoj luci Pleso ugrađena je u povijesni humak Mogila u parku Maksimir za vrijeme njegove obnove (1995.). Na zagrebačkom Hipodromu slavio je Sv. Otac sv. misu pred gotovo milijun vjernika. Hrvatski narod pozvao je na pomirenje i opraštanje, koje ne isključuje, te zakonite sankcije, što će ponoviti i za svoja druga dva posjeta Hrvatskoj (Nagy, 2011, 237-250).

Drugi puta je Sv. Otac pohodio Hrvatsku od 2. do 4. listopada 1998.: Zagreb, Mariju Bistricu, Split i Solin. U Mariji Bistrici za vrijeme svečane mise papa je pred oko pola milijuna vjernika i cijelim državnim vodstvom na čelu s predsjednikom Franjom Tuđmanom proglasio blaženim zagrebačkoga nadbiskupa i kardinala Alojzija Stepinca. Split je pohodio 4. listopada, te slavio misu na Žnjanu, a poslijepodne pohodio je Gospino svetište u Solinu, gdje ga je dočekalo oko 50.000 vjernika, najviše mladih. Na susretu s mladima papa je i sam s njima zapjevao Rajska Djevo kraljice Hrvata, te iz splitske zračne luke odletio za Rim (Nagy, 2011, 360-363). 
Treći put sv. otac Ivan Pavao II. pohodio je Hrvatsku i njezine gradove od 5. do 9. lipnja 2003. godine. Bili su to Rijeka, Osijek-Đakovo, Zadar i Dubrovnik, gdje je proglasio blaženom časnu sestru Mariju Petković, utemeljiteljicu redovničke družbe Kćeri milosrđa. Bilo je to i jubilarno 100. putovanje Ivana Pavla II. izvan Italije u godini u kojoj je navršio srebrni jubilej svoje papinske službe (Nagy,2011, 450-460).

I papa Benedikt XVI. pohodio je Hrvatsku i Zagreb 4.i 5. lipnja 2011., povodom Nacionalnoga dana hrvatskih katoličkih obitelji. Dao je također suglasnost za proglašenje blaženima Drinskih mučenica (2011.), među kojima su i dvije Hrvatice: s. Jula Ivanišević i s. Bernadeta Banja, te hrvatskoga mučenika u Istri svećenika Miroslava Bulešića (2013.).

\subsection{Ulazak Hrvatske u NATO i Europsku uniju — stabilizacija zemlje}

Premda je Hrvatska odmah nakon međunarodnoga priznanja (1992.) željela započeti pregovore o ulasku u Europsku zajednicu i NATO, što je podržavala i Sveta Stolica, nametnute okolnosti, u čijem je žarištu ponajprije obrambeni Domovinski rat (1991.-1995.), ta su pitanja odgođena, te ponovno nakon suđenja u Hagu. Ipak, nakon završenih pregovora s NATO-om, Republika Hrvatska postala je od 1. travnja 2009. članica Sjeverno-atlantskoga vojnoga saveza, i od tada uspješno sudjeluje i u njegovim mirovnim misijama.

Međutim, pregovori o ulasku Hrvatske u Europsku uniju, zbog niza dodatnih okolnosti, otvoreni su 3. listopada 2005. godine, i potrajali još više godina zbog graničnih pitanja i njihova konačnoga rješenja sa Slovenijom. Tako je Republika Hrvatska, nakon svečano potpisanoga ugovora 1. srpnja 2013., postala 28. punopravna članica Europske unije, i pruženi su joj horizonti suradnje sa svijetom, ali i vlastita afirmacija, koja zahtijeva i velika ulaganja vlastitih sposobnosti i znanja. Nakon traženja svojega mjesta, Hrvatska danas uživa i veliki ugled u svijetu, ali i Europskoj uniji. Znamo, Hrvatska će predsjedati Vijećem Europske unije od 1. siječnja do 30. lipnja 2020. godine.

\section{Zaključak}

Premda se hrvatski narod prije stotinu godina i protiv svoje volje našao u prvoj, a potom u drugoj Jugoslaviji, te u objema pretrpio dugotrajna i teška kršenja ljudskih prava i sloboda, uz nametanje marksističke ideologije, pružao je, koliko je mogao, stalni otpor nametnutim režimima i ideologiji. U osloncu na katoličku vjeru i vjernost Svetoj Stolici te zahvaljujući promjenama u svijetu koje je potaknuo i Drugi vatikanski sabor, uspio se je othrvati i održati. Nakon rušenja Berlinskoga zida želio je mirnim putem izići iz okova druge Jugoslavije, ali mu to nije dopustila velikosrpska agresija. U Domovinskom ratu i uz velike žrtve, i uz Božju pomoć izborio je slobodu. Nakon međunarodnoga priznanja i ulaska u UN, Hrvatska je postala članica NATO-a i Europske unije. U svemu tome duhovnu i moralnu potporu pružila joj je Sveta Stolica, osobito sv. otac Ivan Pavao II., koji je i tri puta pohodio Hrvatsku. 


\section{Literatura}

Barunčić Pletikosić, Julija (2017). Katolička Crkva u Hrvatskoj i Domovinski rat 1991.1995.: Stavovi, djelovanje, stradanja. Zagreb: Glas Koncila.

Batelja, Juraj (2000). Alojzije Stepinac nadbiskup zagrebački: Propovijedi, govori, poruke (1934.-1940.). Zagreb: Postulatura blaženoga Alojzija Stepinca.

Batelja, Juraj (2012). Blaženi Alojzije Stepinac: Propovijedi, govori, poruke (1941.-1946.). Zagreb: Postulatura blaženoga Alojzija Stepinca.

Deželić ml., Velimir (2011). Kakvi smo bili?: Zapisi mojoj unučadi: Život zagrebačke obitelji od 1827. do 1953. Sv. 1-2. Zagreb: Družba braća Hrvatskog Zmaja.

Macan, Trpimir (1992). Povijest hrvatskoga naroda. Zagreb: Matica hrvatska.

Miklobušec, Valentin (2016). Isusovci i hrvatski narod V. Zagreb: Filozofsko-teološki institut Družbe Isusove.

Milić, Marijo (1998). Pape od Sv. Petra do Ivana Pavla II. Split: Laus.

Nagy, Božidar (2011). Papa Ivan Pavao II. govori Hrvatima: Pozdravi, govori i poruke 1978.-2005. Zagreb: Filozofsko-teološki institut Družbe Isusove.

Pavličević, Dragutin (2000). Povijest Hrvatske. Zagreb: Grafički zavod Hrvatske.

Srkulj, Stjepan (1925). Kulturno-historijska izložba grada Zagreba. Zagreb: Tipografija.

Szabo, Agneza (2002). Osvrt na život i djelo Marije Kumičić. U: Ivica Matičević (ur.), Okrugli stol Eugen Kumičić: Život i djelo: Zbornik radova. Brseč: Udruga Jenio Sisolski.

Szabo, Agneza; Labus, Alan (2012). Hrvatska povijest: Odabrane teme. Zaprešić: Visoka škola za poslovanje i upravljanje Baltazar Adam Krčelić.

Šanjek, Franjo (1996). Kršćanstvo na hrvatskom prostoru. Zagreb: Kršćanska sadašnjost.

Social and Political Circumstances at the Time of the Journal's Publication: Život (1919-1944) and Obnovljeni Život (1971-2019)

Agneza Szabo*

\section{Summary}

This contribution presents an overview of the most relevant social and political circumstances which the Croatian people underwent in the course of the 20th century and similarly, in conjunction with them, the journal Život, or rather Obnovljeni Život. The significance and content of the journal is not discussed here, however the journal and its hundredth anniversary constitute a part of Croatian history. These are therefore indicated in the title and the article pays tribute to them. This paper discusses a series of social and political circumstances, caused by grave political injustices on the part of governing regimes and power structures, which were the plight of the Croatian people but did not reflect the people's will. The essence of the injustice was the severe limitation on human rights and freedoms. Even in these circumstances the Croatian people sought a solution in the underpinnings of the enduring historical and cultural values of the nation which include the Catholic faith and the Holy See and which, owing to the changes in the world at the core of which was the

* Agneza Szabo, Ph.D., dr.h.c., Retired. E-mail: agneza.szabo@zg.t-com.hr 
Second Vatican Council, did in fact provide a solution. Since then, and after the fall of the Berlin Wall, change was inevitable. Greater Serbian aggression compelled the nation to lawfully defend itself and, with the help of God, gained a merited victory in the Homeland War (1991-1995) and also attained international recognition of its sovereignty as well as of its proper state - the Republic of Croatia (1992). This was followed by entry into NATO and the European Union within which Croatia is worthily esteemed. The Holy See gave Croatia immense support during the entire process, particularly the Holy Father John Paul II.

Key words: Croatia, democracy, regimes, Greater Serbian agression, Homeland War, Holy See 